\title{
Neighborhood and weight-related health behaviors in the Look AHEAD (Action for Health in Diabetes) Study
}

\author{
Tiffany L Gary-Webb*1,2,3, Kesha Baptiste-Roberts², Luu Pham4, Jacqueline Wesche-Thobaben5, Jennifer Patricio6, F \\ Xavier Pi-Sunyer ${ }^{6}$, Arleen F Brown7, LaShanda Jones ${ }^{8}$, Frederick L Brancati2,3 for the Look AHEAD Research Group
}

\begin{abstract}
Background: Previous studies have shown that neighborhood factors are associated with obesity, but few studies have evaluated the association with weight control behaviors. This study aims to conduct a multi-level analysis to examine the relationship between neighborhood SES and weight-related health behaviors.

Methods: In this ancillary study to Look AHEAD (Action for Health in Diabetes) a trial of long-term weight loss among individuals with type 2 diabetes, individual-level data on 1219 participants from 4 clinic sites at baseline were linked to neighborhood-level data at the tract level from the 2000 US Census and other databases. Neighborhood variables included SES (\% living below the federal poverty level) and the availability of food stores, convenience stores, and restaurants. Dependent variables included BMI, eating patterns, weight control behaviors and resource use related to food and physical activity. Multi-level models were used to account for individual-level SES and potential confounders.

Results: The availability of restaurants was related to several eating and weight control behaviors. Compared to their counterparts in neighborhoods with fewer restaurants, participants in neighborhoods with more restaurants were more likely to eat breakfast (prevalence Ratio [PR] 1.29 95\% Cl: 1.01-1.62) and lunch (PR $=1.19,1.04-1.36)$ at non-fast food restaurants. They were less likely to be attempting weight loss $(\mathrm{OR}=0.93,0.89-0.97)$ but more likely to engage in weight control behaviors for food and physical activity, respectively, than those who lived in neighborhoods with fewer restaurants. In contrast, neighborhood SES had little association with weight control behaviors.
\end{abstract}

Conclusion: In this selected group of weight loss trial participants, restaurant availability was associated with some weight control practices, but neighborhood SES was not. Future studies should give attention to other populations and to evaluating various aspects of the physical and social environment with weight control practices.

\section{Background}

It is estimated that 97 million adults in the United States are either overweight or obese [1]. Obesity, defined as a body mass index (BMI) of $30 \mathrm{~kg} / \mathrm{m}^{2}$ or higher in adults, is a complex disease that arises from interactions between multiple genes, as well as behavioral and environmental factors [1]. Furthermore, obesity is a serious risk factor for many chronic conditions (diabetes, hypertension,

*Correspondence: tlg2124@columbia.edu

1 Department of Epidemiology, Columbia Mailman School of Public Health, New York, NY, USA

Full list of author information is available at the end of the article hypercholesterolemia, stroke, heart disease, certain cancers, and arthritis) and has been reported to markedly decrease life expectancy [2-4]. The prevalence of obesity was relatively stable between 1960 and 1980, but has dramatically increased over the past 20 years [5]. Although the health risks of obesity are well established, there is less certainty about the management of the disease. Lifestyle modification programs to address obesity prevention and weight loss have achieved only moderate success, particularly interventions for long-term weight loss [6]. 
New public health approaches to the obesity problem are urgently required. One factor that may play a role in the risk of obesity is the neighborhood environment $[7,8]$. Neighborhood socioeconomic conditions are known to affect health even after controlling for individual-level socio-demographic factors [9-11]. Recent data suggests that the neighborhood environment may influence risk of chronic diseases such as cardiovascular disease, type 2 diabetes, and related health behaviors such as decreased levels of physical activity [12-22]. A few studies have demonstrated that living in neighborhoods with low socio-economic status (SES) is associated with an increased risk of obesity $[23,24]$. However, there are few data on neighborhood and weight-control behaviors. Investigating novel correlates of weight control is necessary given there is overwhelming evidence showing that weight loss is associated with marked improvement in health status, particularly, blood pressure and glucose control [25-27].

Therefore, we conducted a multi-level analysis to examine the relationship between neighborhood SES and weight-related variables at baseline among overweight participants with type 2 diabetes enrolled in the Look AHEAD study. We hypothesized that: 1) poorer neighborhood SES would be associated with poorer eating patterns and weight control behaviors independent of individual-level socio-economic status and 2) more availability of stores with healthy options (i.e. food stores) in the neighborhood would be associated with better eating patterns and weight control behaviors independent of individual-level socio-economic status.

\section{Methods}

\section{Study Population of the Parent Study}

The primary objective of the Look AHEAD study [28] is to examine, in overweight volunteers with type 2 diabetes, the long-term effects of an intensive lifestyle intervention program designed to achieve and maintain weight loss by decreased caloric intake and increased physical activity. The intervention group is compared to a control condition involving a program of diabetes education and support. The primary basis for the comparison is the incidence of serious cardiovascular events. Other outcomes, including cardiovascular disease risk factors, diabetes-related metabolic factors and complications, and the cost-effectiveness of the intensive intervention are also studied. Participants are 5,145 volunteers with type 2 diabetes who are 45-75 years of age and overweight or obese (body mass index $[\mathrm{BMI}] \geq 25 \mathrm{~kg} / \mathrm{m}^{2}$ ).

\section{Study Population of the Ancillary Study}

This ancillary study was conducted at baseline using Look AHEAD participants at 4 clinical sites; Baltimore $(\mathrm{n}$ $=302)$, Philadelphia $(\mathrm{n}=293)$, Pittsburgh $(\mathrm{n}=321)$, and
New York $(n=303)$. Sites were chosen because of their close geographic proximity and similar demographic profile. The total study sample for this ancillary consists of 1219 participants with complete data on neighborhood environment. Addresses were used to identify the corresponding census tracts for each participant (neighborhood) as defined by the 2000 Census using a process called geocoding and software program ArcGIS ${ }^{\mathrm{mm}}$. The program matches imported addresses to geographic maps and other geographic data. Matches are rated with scores from 0 (no match) to 100 (perfect match); we accepted matches with $80 \%$ certainty or more. Once we identified the census tracts and corresponding data for each participant, these data were linked to the individuallevel data collected during the Look AHEAD trial. A description of all of the main variables used in this analysis is summarized in Table 1.

\section{Main Data Sources}

Data are derived from the 2000 US Census long form and include demographic characteristics (age, race, sex), housing characteristics (housing structure, number of rooms, telephone surface), economic characteristics (occupation, place of work and journey to work) and financial characteristics (value of home, rent, utilities cost) for each census tract.

We also used data from the 2004 Consumer Expenditure database which outlines the locality of food stores using a multi-level hierarchical classification system. The data are derived from an extensive modeling effort using the 1994, 1995, 1996, 1997, and 2000 Consumer Expenditure Survey data from the Bureau of Labor Statistics (BLS), in addition to the latest 1998 overview data. The BLS survey averages over 5,000 households four times a year using a rotating sampling frame. We used aggregate data at the census tract level (estimated at 3000-5000 persons).

Participants in the Look AHEAD study underwent extensive data collection at baseline, including interview, physical examination, and blood and urine assays[28]. Although the trial will last over 10 years, this manuscript is restricted to data collected at baseline only. The parent study was approved by the Johns Hopkins Western Institutional Review Board and all participants signed written informed consent to participate in the study.

\section{Key Independent Variables}

Using the Census data, indices of neighborhood socioeconomic status developed by Diez-Roux and Winkleby/ Cubbin, were created using variables such as the \% of persons living below poverty, $\%$ of adults with a college degree, median household income, \% of persons earning interest income, \% of adults in executive/managerial occupations, and \% of adults who are unemployed. After 
Table 1: Selected Characteristics of 1219 Look AHEAD participants

\begin{tabular}{lc}
\hline Characteristics & \\
\hline Socio-demographic Characteristics & \\
Age (years) & $59.5 \pm 6.7$ \\
Sex & \\
$\quad$ Male & $501(41.1)$ \\
Education (years) ${ }^{\dagger}$ & \\
$16+$ & $192(16.2)$ \\
$13-16$ & $389(32.7)$ \\
$\quad \leq 12$ & $607(51.1)$ \\
Race & \\
$\quad$ Black & $327(26.8)$ \\
White & $795(65.2)$ \\
Other & $97(8.0)$ \\
Income & \\
$\quad<\$ 20,000$ & $79(7.5)$ \\
$\quad \$ 20,000-\$ 40,000$ & $184(17.6)$ \\
$\$ 40,000-\$ 60,000$ & $216(20.7)$ \\
$\$ 60,000-\$ 80,000$ & $185(17.7)$ \\
$\geq \$ 80,000$ & $382(36.5)$ \\
Body mass index $\left[\mathrm{BMI}, \mathrm{kg} / \mathrm{m}^{2}\right]$ & $36.1 \pm 5.7$ \\
Overweight $[20-29.9]$ & $163(13.4)$ \\
Obese [30-34.9] & $780(64.0)$ \\
Extreme Obesity[ $\geq 35]$ & $276(22.6)$
\end{tabular}

\section{Neighborhood Census Tract Indicators}

Percent Below Poverty [Range $=0,0.67$ ]

Cubbin Deprivation Score [Range $=-2.9,2.8]$

Diez-Roux Deprivation Score [Range $=-18.7,12.0]$

Food Stores [Range $=0,9]$

Convenience Stores [Range $=0,4]$

Restaurants [Range $=0,104]$

Other Food Stores [Range $=0,9$ ]

Other Food Service [Range $=0,9]$

\section{Dietary Intake (daily)}

Total Fat (\%) $\xi$

$$
\geq 35
$$$$
<35
$$

$164(26.1)$

Saturated Fat (\%) $\xi$

$$
\begin{aligned}
& \geq 10 \\
& <10
\end{aligned}
$$

Fruit \& Vegetable (servings) $\xi$

$$
\begin{aligned}
& <9 \\
& \geq 9
\end{aligned}
$$

\section{Eating Patterns}

Eat breakfast (days/week) ${ }^{\S}$

$$
7 \text { vs }<7
$$

Eat breakfast at a fast food restaurant $€$ $\geq 1$ vs. 0
Table 1: Selected Characteristics of 1219 Look AHEAD participants (Continued)

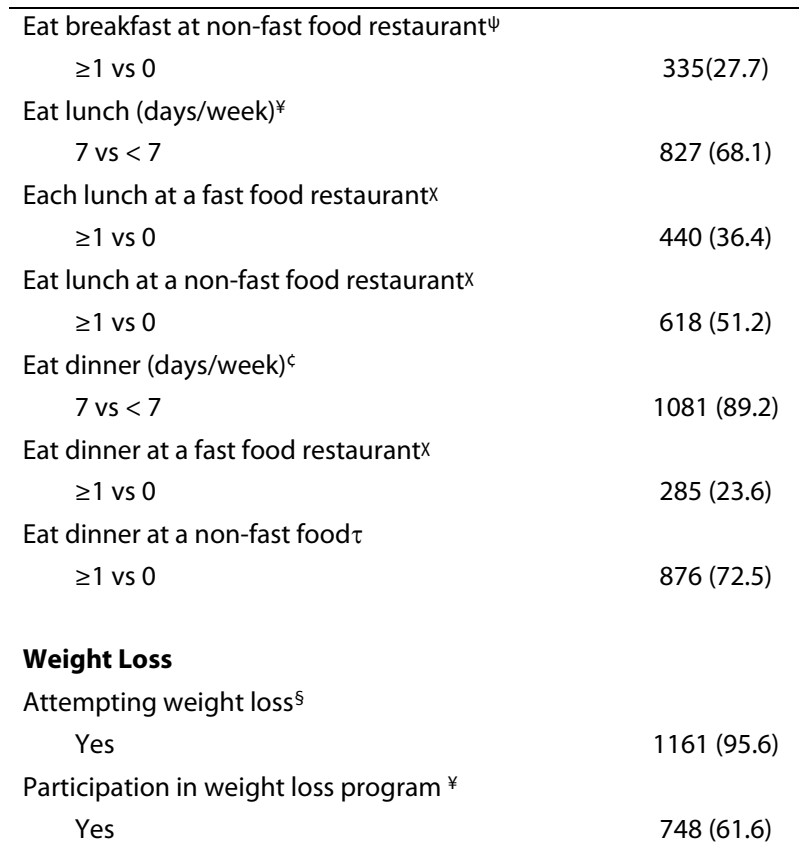

Weight Loss Control Practices (yes/no)

Food

Count fat grams $*$

$194(16.0)$

Cut out between meal snacking $\tau$

$428(35.4)$

Eat less high carbohydrate foods $€$

$713(58.9)$

Reduce the number of calories eatená

$661(54.5)$

Record what you eat daily $\gamma$

$442(36.4)$

Decrease fat intake $\tau$

$636(52.6)$

Eat meal replacements

$193(15.9)$

Cut out sweets and junk food from diet $\quad 763(63.0)$

Increase fruit and vegetables

$789(65.3)$

Fast or go without the food entirelyà 74 (6.1)

Count caloriesà

$193(15.9)$

Eat special low calorie diet foods

$256(21.2)$

$222(18.5)$

430 (35.5)

Eat less meat€

$4.92 \pm 3.06$ 13]

\section{Physical Activity}

Keep a graph of exercise ${ }^{¥} \quad 87(7.2)$

Increase your exercise levelsá $\quad 671$ (55.3)

Use home exercise equipment ${ }^{\S} \quad 374$ (30.8)

Record exercise daily $¥ 149$ (12.3)

Weight control physical activity outcome $\quad 1.05 \pm 0.99$

summary score [0-4]

\section{Weight Control}

Keep graph of weight ${ }^{\S}$

$82(6.8)$

Go to a weight loss group $\$ \quad 173(14.2)$

Take diet pills§

Other weight control activities 
Table 1: Selected Characteristics of 1219 Look AHEAD participants (Continued)

\begin{tabular}{|c|c|}
\hline Smoke cigarettes ${ }^{\S}$ & $51(4.2)$ \\
\hline Weight control weight loss summary score [0-4] & $0.38 \pm 0.64$ \\
\hline \multicolumn{2}{|l|}{ Resource Use (yes/no) } \\
\hline \multicolumn{2}{|l|}{ Food } \\
\hline $\begin{array}{l}\text { Food preparation equipment purchased in the } \\
\text { past year§ }\end{array}$ & $621(51.1)$ \\
\hline \multicolumn{2}{|l|}{ Physical Activity } \\
\hline Positive feeling about exercise $₫$ & $765(63.9)$ \\
\hline Indoor exercise purchases in the past year $\gamma$ & $411(33.8)$ \\
\hline Outdoor exercise purchases in the past year $\gamma$ & $103(8.5)$ \\
\hline Gym membership purchase in the past year $\dot{n}$ & $265(21.7)$ \\
\hline $\begin{array}{l}\text { Resource use physical activity outcomes summary } \\
\text { score }\end{array}$ & $1.27 \pm 0.96$ \\
\hline \multicolumn{2}{|l|}{ Weight Control } \\
\hline $\begin{array}{l}\text { Class membership/services for weight loss } \\
\text { purchases in the past year§ }\end{array}$ & $398(32.8)$ \\
\hline Joined a weight loss program in the past yeará & $161(13.3)$ \\
\hline $\begin{array}{l}\text { Resource use weight control outcomes summary } \\
\text { score }\end{array}$ & $0.46 \pm 0.61$ \\
\hline \multicolumn{2}{|c|}{ 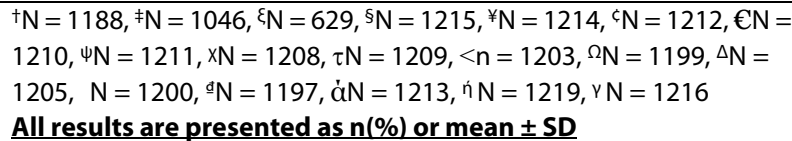 } \\
\hline r SES & \\
\hline
\end{tabular}

considering these measures used in previous studies [2931 , we ultimately decided on the single item "\% of individuals in the census tract living below the federal poverty line" because this measure is highly correlated with other census-based indices and has been shown to be similarly predictive of health outcomes [31].

Data on food availability in the census tract was categorized using the North American Industry Classification System (NAICS) definitions into: 1) food stores these establishments retail food and beverages merchandise from fixed point-of-sale locations. Establishments in this subsector have special equipment (e.g., freezers, refrigerated display cases, refrigerators) for displaying food and beverage goods. They have staff trained in the processing of food products to guarantee the proper storage and sanitary conditions required by regulatory authority; includes grocery stores and supermarkets; 2) convenience stores these establishments primarily engaged in retailing a limited line of goods that generally includes milk, bread, soda, and snacks; and 3) restaurants these establishments primarily engaged in providing food services to patrons who order and are served while seated (i.e. waiter/waitress service and pay after eating. they may provide this type of food service to patrons in combination with selling alcoholic beverages, providing carry out services, or presenting live non-theatrical entertainment; includes full-service, fast food, and carryout.

\section{Key Dependent Variables}

Dependent variables included eating patterns, weight loss control practices, and BMI. Variables capturing participant eating patterns consisted of reports of eating breakfast, lunch, and dinner and whether they ate at fast-food or non-fast food restaurants. Dietary intake, daily total fat, saturated fat, and fruit and vegetable intake was measured on a sub-set of individuals at baseline (629 participants in the ancillary study). Questions related to attempting weight loss and participating in weight loss programs and weight loss control practices related to food, physical activity, and weight control resource use were also examined. Examples of resources use include purchases of exercise equipment or weight loss program membership. For multivariate analysis purposes, individual questions were summarized to create separate scores for resource use related to physical activity, weight control, and food preparation. BMI was calculated using measured height and weight.

\section{Statistical Analysis}

In this analysis, the main independent variables were the neighborhood factors and the main dependent variables were individual-level weight-related variables from the Look AHEAD study. Descriptive statistics were used to describe the study population.

Multi-level analyses were used to analyze the aggregate and individual level data [32-34]. Recognizing that when studying group-level variables, individuals are nested within those groups, multi-level analyses are designed to account for this clustering. Specifically, the model building first identifies the most predictive set of individuallevel variables. Then aggregate-level variables are added. At each level, all variables and their interaction effects are tested. Random effects terms are then added as additional parameters to account for extra area-level variability not explained by the model and included variables (overdispersion) [32].

In the current study, the association between neighborhood factors (\% poverty, food availability for the census tract) and individual-level weight-related outcomes were determined while accounting for individual level SES (personal income and education). This enabled us to determine the independent effects of the neighborhood SES. Other potential confounders included in the models were: age, sex, and race. All analyses were conducted using STATA statistical software, version 9.

\section{Results}

\section{Selected Baseline Characteristics of Study Participants}

Selected baseline characteristics of the study participants are presented in Table 1. Participants were on average $59.5 \pm 6.7$ years of age, $41 \%$ male, and $27 \%$ were Black/ African American. About half of participants had at least 
some college education; the majority of participants had annual incomes $>\$ 40,000$. All participants were at least overweight or obese $\left(B M I>25 \mathrm{~kg} / \mathrm{m}^{2}\right)$,eligibility criteria for Look AHEAD.

Participant neighborhoods were diverse. Of all the neighborhoods represented in the study, the mean \% of those living below the federal poverty level was $11 \%$. Neighborhoods on average had $1.3 \pm 1.5$ food stores, 0.6 \pm 0.8 convenience stores, and $6.8 \pm 10.8$ restaurants (fast food and non-fast food). Overall, there were 920 unique census tracts represented in the study; Baltimore $=201$, New York $=257$, Philadelphia $=245$, Pittsburgh $=217$. The number of participants per census tract ranged from 1-6.

With respect to dietary intake and eating patterns, most participants did not meet the recommended intakes for total fat, saturated fat, and fruit and vegetables. Most participants reported eating breakfast, lunch and dinner every day, and about a quarter reported eating those meals at a fast food restaurant more than once a week.

The vast majority of participants reported that they were currently attempting weight loss (96\%) and 62\% reported that they had participated in a weight loss program before the study. Many reported various weight control strategies such as cutting out sweets and junk food from their diets $(63 \%)$, increasing fruit and vegetables (65\%), and increasing exercise levels (55.3). With respect to resources spent on food, physical activity, and weight control, the most common were purchase of food preparation equipment (51\%), indoor exercise equipment (33.8\%), and class membership services for weight loss (33\%).

\section{Association between Neighborhood and Eating Patterns}

Table 2 outlines the association between neighborhood and eating patterns. Participants living in neighborhoods with more restaurantswere significantly more likely to eat breakfast and lunch at restaurants that were not fast food restaurants compared to those living in neighborhoods with fewer restaurants. Furthermore, they were significantly more likely to eat dinner 7 days per week.

\section{Association between Neighborhood and Weight Loss Control Practices}

Neighborhood SES had little association with weight control practices (see Table 3). Those who lived in neighborhoods with more restaurants were less likely to be attempting weight loss, and more likely to participate in weight loss control practices related to food and physical activity than those who lived in neighborhoods with fewer restaurants. There was no significant association seen for neighborhood and BMI.

\section{Association between Neighborhood and Resource Use}

Those living in neighborhoods with more poverty were significantly more likely to have purchased food preparation equipment in the past year compared to those living in neighborhoods with the least poverty $(\mathrm{PR}=1.36$, see Table 4).

\section{Association between Neighborhood and Dietary Intake}

Contrary to our hypothesis, those who lived in poorer neighborhoods had lower intakes of total and saturated fat compared to those living in wealthier neighborhoods (Table 5). This did not appear to be influenced by total caloric intake.

\section{Discussion}

Our results suggest that among this group of overweight adults with type 2 diabetes in the Look AHEAD study that: 1) the presence of more restaurants in the neighborhood was associated with eating at non-fast food restaurants and with participation in several food and physical activity weight control practices; 2) neighborhood SES was only associated with a few of the weight-related factors. These conclusions are supported by a study with a diverse range of neighborhoods, detailed individual-level data, and a large percentage of minority participants.

Studies of neighborhood and health have generally focused on the physical built environment and its relation to physical activity[35-41]. Some studies have evaluated neighborhood and dietary patterns[42-44], and more recent studies have evaluated obesity or weight status as an outcome [45-50]. Few studies, to date, have evaluated neighborhood SES or other characteristics with weight control practices. Our study, which was conducted within a large-scale weight loss trial, had the strength of including a wealth of individual-level data on eating patterns, weight control practices, along with resource use for weight loss purposes.

There were, however, a few limitations. First, using the census tract as a proxy for neighborhood has been criticized, however, many studies have used this indicator, allowing us to compare our findings across studies. Furthermore, the wealth of data available from the US Census provides a comprehensive view of this geographic entity. Similarly, the neighborhood data may not have represented the entire baseline time-period for the Look AHEAD study. Data used were from the 2000 Census and 2004 Consumer database; Look AHEAD participants were recruited from 2001-2004. Neighborhoods are constantly changing, however the time-frame for the data used was close to the study recruitment period. Second, given the eligibility criteria for entry into the study, the population was fairly homogeneous with respect to some factors. One example was weight, which may explain why 
Table 2: Prevalence Ratios and 95\% confidence intervals for Neighborhood Indicators and Eating Patterns among 1219 participants in the Look AHEAD Study

\begin{tabular}{|c|c|c|c|c|c|c|c|c|c|c|}
\hline $\begin{array}{l}\text { Neighborhood } \\
\text { Indicator }\end{array}$ & & $\begin{array}{c}\text { Eat } \\
\text { breakfast } \\
\text { (days/ } \\
\text { week) }\end{array}$ & $\begin{array}{l}\text { Eat breakfast at a } \\
\text { fast food } \\
\text { restaurant (days/ } \\
\text { week) }\end{array}$ & $\begin{array}{l}\text { Eat breakfast at } \\
\text { restaurants that are } \\
\text { not fast food } \\
\text { restaurants (days/ } \\
\text { week) }\end{array}$ & $\begin{array}{l}\text { Eat lunch } \\
\text { (days/ } \\
\text { week) }\end{array}$ & $\begin{array}{l}\text { Eat lunch at a } \\
\text { fast food } \\
\text { restaurant } \\
\text { (days/week) }\end{array}$ & $\begin{array}{c}\text { Eat lunch at } \\
\text { restaurants } \\
\text { that are not fast } \\
\text { food } \\
\text { restaurants } \\
\text { (days/week) }\end{array}$ & $\begin{array}{c}\text { Eat } \\
\text { dinner } \\
\text { (days/ } \\
\text { week) }\end{array}$ & $\begin{array}{l}\text { Eat dinner at a } \\
\text { fast food } \\
\text { restaurant } \\
\text { (days/week) }\end{array}$ & $\begin{array}{l}\text { Eat dinner at } \\
\text { restaurants that } \\
\text { are not fast food } \\
\text { restaurants } \\
\text { (days/week) }\end{array}$ \\
\hline \multirow[t]{2}{*}{ Below Poverty (\%) ${ }^{\dagger}$} & 2 & $\begin{array}{c}1.22 \\
(0.98,1.53)\end{array}$ & $\begin{array}{c}0.93 \\
(0.67,1.28)\end{array}$ & $\begin{array}{c}0.89 \\
(0.70,1.14)\end{array}$ & $\begin{array}{c}0.99 \\
(0.79,1.24)\end{array}$ & $\begin{array}{c}1.04 \\
(0.86,1.27)\end{array}$ & $\begin{array}{c}0.96 \\
(0.84,1.10)\end{array}$ & $\begin{array}{c}0.92 \\
(0.71,1.49)\end{array}$ & $\begin{array}{c}1.17 \\
(0.88,1.54)\end{array}$ & $\begin{array}{c}1.00 \\
(0.92,1.08)\end{array}$ \\
\hline & 3 & $\begin{array}{c}1.12 \\
(0.88,1.45)\end{array}$ & $\begin{array}{c}1.11 \\
(0.79,1.55)\end{array}$ & $\begin{array}{c}1.08 \\
(0.83,1.40)\end{array}$ & $\begin{array}{c}1.17 \\
(0.93,1.48)\end{array}$ & $\begin{array}{c}0.99 \\
(0.80,1.23)\end{array}$ & $\begin{array}{c}1.03 \\
(0.89,1.20)\end{array}$ & $\begin{array}{c}1.25 \\
(0.77,2.03)\end{array}$ & $\begin{array}{c}1.13 \\
(0.84,1.53)\end{array}$ & $\begin{array}{c}1.00 \\
(0.92,1.10)\end{array}$ \\
\hline Food Stores & $\geq 1$ vs $<1$ & $\begin{array}{c}1.02 \\
(0.85,1.23)\end{array}$ & $\begin{array}{c}1.22 \\
(0.94,1.10)\end{array}$ & $\begin{array}{c}1.03 \\
(0.84,1.26)\end{array}$ & $\begin{array}{c}1.20 \\
(0.99,1.44)\end{array}$ & $\begin{array}{c}0.93 \\
(0.79,1.09)\end{array}$ & $\begin{array}{c}1.00 \\
(0.89,1.11)\end{array}$ & $\begin{array}{c}1.07 \\
(0.73,1.56)\end{array}$ & $\begin{array}{c}1.06 \\
(0.84,1.33)\end{array}$ & $\begin{array}{c}0.96 \\
(0.89,1.02)\end{array}$ \\
\hline Convenience Stores & $\geq 1$ vs $<1$ & $\begin{array}{c}0.99 \\
(0.82,1.18)\end{array}$ & $\begin{array}{c}1.38 \\
(1.08,1.77)\end{array}$ & $\begin{array}{c}1.15 \\
(0.93,1.63)\end{array}$ & $\begin{array}{c}0.99 \\
(0.83,1.17)\end{array}$ & $\begin{array}{c}1.06 \\
(0.90,1.24)\end{array}$ & $\begin{array}{c}0.99 \\
(0.84,1.11)\end{array}$ & $\begin{array}{c}1.29 \\
(0.90,1.84)\end{array}$ & $\begin{array}{c}1.06 \\
(0.86,1.32)\end{array}$ & $\begin{array}{c}0.94 \\
(0.88,1.01)\end{array}$ \\
\hline \multirow[t]{2}{*}{ Restaurants $^{\dagger}$} & 2 & $\begin{array}{c}1.07 \\
(0.86,1.33)\end{array}$ & $\begin{array}{c}0.94 \\
(0.69,1.30)\end{array}$ & $\begin{array}{c}1.11 \\
(0.87,1.43)\end{array}$ & $\begin{array}{l}1.24 \\
(1.00 \\
1.53)\end{array}$ & $\begin{array}{c}0.94 \\
(0.29,1.30)\end{array}$ & $\begin{array}{c}1.08 \\
(0.94,1.25)\end{array}$ & $\begin{array}{c}0.99 \\
(0.62,1.58)\end{array}$ & $\begin{array}{c}0.86 \\
(0.65,1.11)\end{array}$ & $\begin{array}{c}0.97 \\
(0.88,1.06)\end{array}$ \\
\hline & 3 & $\begin{array}{c}1.15 \\
(0.94,1.42)\end{array}$ & $\begin{array}{c}1.27 \\
(0.95,1.70)\end{array}$ & $\begin{array}{c}1.28 \\
(1.01,1.62)\end{array}$ & $\begin{array}{r}1.24 \\
(1.00 \\
1.53)\end{array}$ & $\begin{array}{c}0.91 \\
(0.75,1.11)\end{array}$ & $\begin{array}{c}1.19 \\
(1.04,1.36)\end{array}$ & $\begin{array}{r}1.61 \\
(1.06, \\
2.45)\end{array}$ & $\begin{array}{c}1.01 \\
(0.79,1.29)\end{array}$ & $\begin{array}{c}1.03 \\
(0.95,1.11)\end{array}$ \\
\hline
\end{tabular}


Table 3: Analyses for Neighborhood Indicators, and Weight Control and BMI among 1219 participants in the Look AHEAD Study

\begin{tabular}{|c|c|c|c|c|c|c|c|}
\hline $\begin{array}{l}\text { Neighborhood } \\
\text { Indicator }\end{array}$ & Tertile & $\begin{array}{c}\text { Weight Loss } \\
\text { (yes/no) PR } \\
(95 \% \mathrm{CI})\end{array}$ & $\begin{array}{c}\text { Past Weight } \\
\text { Loss } \\
\text { Program } \\
\text { Participatio } \\
\text { n (yes/no) } \\
\text { PR } 95 \% \mathrm{Cl}\end{array}$ & $\begin{array}{c}\text { Weight } \\
\text { Control Food } \\
\text { B coefficient } \\
(95 \% \mathrm{Cl})\end{array}$ & $\begin{array}{c}\text { Weight Control } \\
\text { Physical Activity } \\
\text { B coefficient } \\
(95 \% \mathrm{Cl})\end{array}$ & $\begin{array}{c}\text { Weight } \\
\text { Control B } \\
\text { coefficient } \\
(95 \% \mathrm{Cl})\end{array}$ & $\begin{array}{l}\text { BMI }(\mathrm{kg} / \mathrm{m} 2) \quad \beta \\
\text { coefficient } \\
(95 \% \mathrm{Cl})\end{array}$ \\
\hline \multirow[t]{2}{*}{ Below Poverty ${ }^{\dagger}(\%)$} & 2 & $\begin{array}{c}0.88 \\
(0.80,0.97)\end{array}$ & $\begin{array}{c}0.94 \\
(0.86,1.03)\end{array}$ & $\begin{array}{c}-0.24 \\
(-0.68,0.19)\end{array}$ & $\begin{array}{c}0.01 \\
(-0.13,0.16)\end{array}$ & $\begin{array}{c}0.08 \\
(-0.01,0.18)\end{array}$ & $\begin{array}{c}0.01 \\
(-0.86,0.86)\end{array}$ \\
\hline & 3 & $\begin{array}{c}0.89 \\
(0.81,0.98)\end{array}$ & $\begin{array}{c}1.02 \\
(0.92,1.12)\end{array}$ & $\begin{array}{c}0.17 \\
(-0.32,0.67)\end{array}$ & $\begin{array}{c}0.10 \\
(-0.05,0.25)\end{array}$ & $\begin{array}{c}0.03 \\
(-0.08,0.13)\end{array}$ & $\begin{array}{c}0.42 \\
(-0.54,1.39)\end{array}$ \\
\hline Food Stores & $\geq 1$ vs $<1$ & $\begin{array}{c}0.96 \\
(0.94,0.99)\end{array}$ & $\begin{array}{c}0.98 \\
(0.91,1.06)\end{array}$ & $\begin{array}{c}0.29 \\
(-0.08,0.67)\end{array}$ & $\begin{array}{c}0.18 \\
(0.06,0.30)\end{array}$ & $\begin{array}{c}0.10 \\
(0.02,0.18)\end{array}$ & $\begin{array}{c}0.34 \\
(-0.38,1.07)\end{array}$ \\
\hline Convenience Stores & $\geq 1$ vs $<1$ & $\begin{array}{c}0.99 \\
(0.97,1.02)\end{array}$ & $\begin{array}{c}0.95 \\
(0.88,1.03)\end{array}$ & $\begin{array}{c}-0.19 \\
(-0.55,0.16)\end{array}$ & $\begin{array}{c}0.01 \\
(-0.11,0.13)\end{array}$ & $\begin{array}{c}-0.04 \\
(-0.12,0.03)\end{array}$ & $\begin{array}{c}-0.11 \\
(-0.82,0.61)\end{array}$ \\
\hline \multirow[t]{2}{*}{ Restaurants $^{\dagger}$} & 2 & $\begin{array}{c}1.11 \\
(1.05,1.17)\end{array}$ & $\begin{array}{c}1.06 \\
(0.97,1.17)\end{array}$ & $\begin{array}{c}-0.03 \\
(-0.47,0.40)\end{array}$ & $\begin{array}{c}0.06 \\
(-0.08,0.20)\end{array}$ & $\begin{array}{c}0.004 \\
(-0.09,0.10)\end{array}$ & $\begin{array}{c}-0.16 \\
(-1.01,0.70)\end{array}$ \\
\hline & 3 & $\begin{array}{c}0.93 \\
(0.89,0.97)\end{array}$ & $\begin{array}{c}1.00 \\
(0.91,1.09)\end{array}$ & $\begin{array}{c}0.42 \\
(0.005,0.84)\end{array}$ & $\begin{array}{c}0.24 \\
(0.09,0.38)\end{array}$ & $\begin{array}{c}0.07 \\
(-0.02,0.17)\end{array}$ & $\begin{array}{c}0.40 \\
(-0.45,1.26)\end{array}$ \\
\hline
\end{tabular}

All models adjusted for age, sex, education, income and race

${ }^{\dagger}$ All represent comparisons to tertile 1 (reference groups)

there was little variation of BMI status by neighborhood. This may explain many of our negative findings. In a future study, we plan to conduct longitudinal analyses and determine how neighborhood influences response to the weight loss intervention. The longitudinal analyses should show more variation in the dependent variables as individuals respond differently to the intervention. Furthermore, as this was an exploratory study, there were many negative findings that may have been due to low statistical power.

Table 4: Analyses for Neighborhood Indicators, Weight Control Practices and Resource Use

\begin{tabular}{|c|c|c|c|c|}
\hline $\begin{array}{l}\text { Neighborhood } \\
\text { Indicator }\end{array}$ & Tertile & $\begin{array}{c}\text { Resource Use Physical Activity } \beta \\
\text { coefficient }(95 \% \mathrm{Cl})\end{array}$ & $\begin{array}{c}\text { Resource Use Weight Control } \beta \\
\text { coefficient }(95 \% \mathrm{Cl})\end{array}$ & $\begin{array}{c}\text { Food preparation equipment } \\
\text { purchased in the past year (yes/ } \\
\text { no) PR }(95 \% \mathrm{Cl})\end{array}$ \\
\hline \multirow[t]{2}{*}{ Below Poverty ${ }^{\dagger}(\%)$} & 2 & $\begin{array}{c}-0.08 \\
(-0.23,0.06)\end{array}$ & $\begin{array}{c}0.05 \\
(-0.04,0.14)\end{array}$ & $\begin{array}{c}1.09 \\
(0.93,1.28)\end{array}$ \\
\hline & 3 & $\begin{array}{c}0.02 \\
(-0.14,0.19)\end{array}$ & $\begin{array}{c}0.04 \\
(-0.07,0.15)\end{array}$ & $\begin{array}{c}1.36 \\
(1.16,1.59)\end{array}$ \\
\hline Food Stores & $\begin{array}{l}\geq 1 \text { vs } \\
<1\end{array}$ & $\begin{array}{c}-0.06 \\
(-0.18,0.07)\end{array}$ & $\begin{array}{c}0.03 \\
(-0.04,0.11)\end{array}$ & $\begin{array}{c}1.03 \\
(0.92,1.17)\end{array}$ \\
\hline Convenience Stores & $\begin{array}{l}\geq 1 \text { vs } \\
<1\end{array}$ & $\begin{array}{c}-0.02 \\
(-0.14,0.10)\end{array}$ & $\begin{array}{c}-0.04 \\
(-0.12,0.03)\end{array}$ & $\begin{array}{c}0.90 \\
(0.80,1.02)\end{array}$ \\
\hline \multirow[t]{2}{*}{ Restaurants $^{\dagger}$} & 2 & $\begin{array}{c}0.06 \\
(-0.09,0.20)\end{array}$ & $\begin{array}{c}-0.02 \\
(-0.11,0.07)\end{array}$ & $\begin{array}{c}1.09 \\
(0.96,1.25)\end{array}$ \\
\hline & 3 & $\begin{array}{c}-0.05 \\
(-0.19,0.09)\end{array}$ & $\begin{array}{c}0.09 \\
(-0.004,0.18)\end{array}$ & $\begin{array}{c}0.94 \\
(0.82,1.90)\end{array}$ \\
\hline
\end{tabular}

All models adjusted for age, sex, education, income and race

${ }^{\dagger}$ All represent comparisons to tertile 1 (reference groups) 
Table 5: Adjusted Prevalence Ratios, $\beta$ coefficients and $95 \%$ confidence intervals for Neighborhood Indicators and Dietary Intake among 629 participants in the Look AHEAD Study

\begin{tabular}{|c|c|c|c|c|c|}
\hline $\begin{array}{l}\text { Neighborhood } \\
\text { Indicator }\end{array}$ & Tertile & $\begin{array}{c}\text { Total calories } \\
\text { (kcal) } \boldsymbol{\beta} \\
\text { coefficient (95\% } \\
\text { Cl) }\end{array}$ & $\begin{array}{c}\% \text { Total Fat }(35+ \\
\text { vs }<35)\end{array}$ & $\begin{array}{c}\text { \% Saturated Fat } \\
(10+\text { vs. }<10)\end{array}$ & $\begin{array}{c}\text { Fruit \& } \\
\text { Vegetable }(9+\text { vs } \\
<9 \text { servings })\end{array}$ \\
\hline \multirow[t]{2}{*}{$\begin{array}{c}\text { Below Poverty }{ }^{\dagger} \\
(\%)\end{array}$} & 2 & $\begin{array}{c}56.05 \\
(-123.63,235.73)\end{array}$ & $\begin{array}{c}0.53 \\
(0.32,0.87)\end{array}$ & $\begin{array}{c}0.54 \\
(0.30,0.98)\end{array}$ & $\begin{array}{c}0.84 \\
(0.35,2.03)\end{array}$ \\
\hline & 3 & $\begin{array}{c}-61.63 \\
(-255.56,132.30)\end{array}$ & $\begin{array}{c}0.57 \\
(0.33,0.99)\end{array}$ & $\begin{array}{c}0.55 \\
(0.29,1.06)\end{array}$ & $\begin{array}{c}1.92 \\
(0.66,5.61)\end{array}$ \\
\hline Food Stores & $\geq 1$ vs $<1$ & $\begin{array}{c}-86.13 \\
(-234.68,62.42)\end{array}$ & $\begin{array}{c}1.02 \\
(0.69,1.53)\end{array}$ & $\begin{array}{c}1.28 \\
(0.81,2.00)\end{array}$ & $\begin{array}{c}1.34 \\
(0.66,2.73)\end{array}$ \\
\hline $\begin{array}{l}\text { Convenience } \\
\text { Stores }\end{array}$ & $\geq 1$ vs $<1$ & $\begin{array}{c}-0.06 \\
(-146.58,146.46)\end{array}$ & $\begin{array}{c}1.02 \\
(0.69,1.52)\end{array}$ & $\begin{array}{c}1.18 \\
(0.76,1.83)\end{array}$ & $\begin{array}{c}1.64 \\
(0.79,3.41)\end{array}$ \\
\hline \multirow[t]{2}{*}{ Restaurants $^{\dagger}$} & 2 & $\begin{array}{c}-63.54 \\
(-236.99,109.90)\end{array}$ & $\begin{array}{c}1.31 \\
(0.81,2.11)\end{array}$ & $\begin{array}{c}1.00 \\
(0.60,1.65)\end{array}$ & $\begin{array}{c}1.26 \\
(0.56,2.83)\end{array}$ \\
\hline & 3 & $\begin{array}{c}68.86 \\
(-108.78,246.49)\end{array}$ & $\begin{array}{c}1.18 \\
(0.73,1.91)\end{array}$ & $\begin{array}{c}1.17 \\
(0.67,2.03)\end{array}$ & $\begin{array}{c}1.24 \\
(0.52,2.94)\end{array}$ \\
\hline
\end{tabular}

${ }^{\dagger}$ All represent comparisons to tertile 1 (reference groups)

All models adjusted for age, sex, education, income and race

\section{Conclusion}

Future studies should evaluate neighborhood in relation to weight loss behaviors in other populations and further explore the impact of various aspects of the physical and social neighborhood environment. Now that individuallevel correlates of healthy weight and weight loss are fairly well understood, attention should be given to other social and environmental determinants that may have a substantial impact. In addition to policy changes such as those that regulate the unhealthy selections in restaurants on an environmental level, incorporating teaching points on influences such as portion control and choosing health options in restaurants should contribute to more successful weight-loss interventions.

\section{Competing interests}

The authors declare that they have no competing interests.

\section{Authors' contributions}

TLG and FLB were responsible for the conception and design of the study. KB was responsible for the data management and data analysis. LP advised on the statistical analysis. TLG drafted the manuscript. KB, JW, JP, XFP, AFB, LJ, FLB were responsible for critical review of the manuscript and interpretation of findings. All authors have read and approved the final manuscript.

\section{Acknowledgements}

The authors would like to acknowledge the Look AHEAD staff and participants who made this research possible.

This project was funded by grants from the National Institutes of Health. Dr. Gary-Webb was funded by grants from the NIDDK (U01-DK57149-05S1) and NHLBI (K01-HL084700) and Dr. Brancati was funded by a grant from the NIDDK
(K24-DK6222). The authors would like to acknowledge the Look AHEAD research group, which has been previously described (ref 26). Look AHEAD Research Group at Baseline Clinical Sites

The Johns Hopkins Medical Institutions Frederick Brancati, MD, MHS; Debi Celnik, MS, RD, LD; Jeff Honas, MS; Jeanne Clark, MD, MPH; Jeanne Charleston, RN; Lawrence Cheskin, MD; Kerry Stewart, EdD; Richard Rubin, PhD; Kathy Horak, RD

Pennington Biomedical Research Center George A. Bray, MD; Kristi Rau; Allison Strate, RN; Frank L. Greenway, MD; Donna H. Ryan, MD; Donald Williamson, PhD; Elizabeth Tucker; Brandi Armand, LPN; Mandy Shipp, RD; Kim Landry; Jennifer Perault

The University of Alabama at Birmingham Cora E. Lewis, MD, MSPH; Sheikilya Thomas MPH; Vicki DiLillo, PhD; Monika Safford, MD; Stephen Glasser, MD; Clara Smith, MPH; Cathy Roche, RN; Charlotte Bragg, MS, RD, LD; Nita Webb, MA; Staci Gilbert, MPH; Amy Dobelstein; L. Christie Oden; Trena Johnsey Harvard Center

Massachusetts General Hospital: David M. Nathan, MD; Heather Turgeon, RN; Kristina P. Schumann, BA; Enrico Cagliero, MD; Kathryn Hayward, MD; Linda Delahanty, MS, RD; Barbara Steiner, EdM; Valerie Goldman, MS, RD; Ellen Anderson, MS, RD; Laurie Bissett, MS, RD; Alan McNamara, BS; Richard Ginsburg, PhD; Virginia Harlan, MSW; Theresa Michel, MS

Joslin Diabetes Center: Edward S. Horton, MD; Sharon D. Jackson, MS, RD, CDE; Osama Hamdy, MD, PhD; A. Enrique Caballero, MD; Sarah Ledbury, MEd, RD; Maureen Malloy, BS; Ann Goebel-Fabbri, PhD; Kerry Ovalle, MS, RCEP, CDE; Sarah Bain, BS; Elizabeth Bovaird, BSN,RN; Lori Lambert, MS, RD Beth Israel Deaconess Medical Center: George Blackburn, MD, PhD; Christos Mantzoros, MD, DSc; Ann McNamara, RN; Heather McCormick, RD

University of Colorado Health Sciences Center James O. Hill, PhD; Marsha Miller, MS, RD; Brent VanDorsten, PhD; Judith Regensteiner, PhD; Robert Schwartz, MD; Richard Hamman, MD, DrPH; Michael McDermott, MD; JoAnn Phillipp, MS; Patrick Reddin, BA; Kristin Wallace, MPH; Paulette Cohrs, RN, BSN; April Hamilton, BS; Salma Benchekroun, BS; Susan Green; Loretta Rome, TRS; Lindsey Munkwitz, BS 
Baylor College of Medicine John P. Foreyt, PhD; Rebecca S. Reeves, DrPH, RD; Henry Pownall, PhD; Peter Jones, MD; Ashok Balasubramanyam, MD; Molly Gee, MEd, RD

University of California at Los Angeles School of Medicine Mohammed F. Saad, MD; Ken C. Chiu, MD; Siran Ghazarian, MD; Kati Szamos, RD; Magpuri Perpetua, RD; Michelle Chan, BS; Medhat Botrous

The University of Tennessee Health Science Center

University of Tennessee East. Karen C. Johnson, MD, MPH; Leeann Carmichael, $\mathrm{RN}$; Lynne Lichtermann, RN, BSN

University of Tennessee Downtown. Abbas E. Kitabchi, PhD, MD; Jackie Day, RN; Helen Lambeth, RN, BSN; Debra Force, MS, RD, LDN; Debra Clark, LPN; Andrea Crisler, MT, Donna Green, RN; Gracie Cunningham; Maria Sun, MS, RD, LDN; Robert Kores, PhD; Renate Rosenthal, PhD; and Judith Soberman, MD University of Minnesota Robert W. Jeffery, PhD; Carolyn Thorson, CCRP; John P. Bantle, MD; J. Bruce Redmon, MD; Richard S. Crow, MD; Jeanne Carls, MEd; Carolyne Campbell; La Donna James; T. Ockenden, RN; Kerrin Brelje, MPH, RD; M. Patricia Snyder, MA, RD; Amy Keranen, MS; Cara Walcheck, BS, RD; Emily Finch, MA; Birgitta I. Rice, MS, RPh, CHES; Vicki A. Maddy, BS, RD; Tricia Skarphol, BS

St. Luke's Roosevelt Hospital Center Xavier Pi-Sunyer, MD; Jennifer Patricio, MS; Jennifer Mayer, MS; Stanley Heshka, PhD; Carmen Pal, MD; Mary Anne Holowaty, MS, CN; Diane Hirsch, RNC, MS, CDE

University of Pennsylvania Thomas A. Wadden, PhD; Barbara J. MaschakCarey, MSN, CDE; Gary D. Foster, PhD; Robert I. Berkowitz, MD; Stanley Schwartz, MD; Shiriki K. Kumanyika, PhD, RD, MPH; Monica Mullen, MS, RD; Louise Hesson, MSN; Patricia Lipschutz, MSN; Anthony Fabricatore, PhD; Canice Crerand, PhD; Robert Kuehnel, PhD; Ray Carvajal, MS; Renee Davenport; Helen Chomentowski

University of Pittsburgh David E. Kelley, MD; Jacqueline Wesche -Thobaben, RN,BSN,CDE; Lewis Kuller, MD, DrPH.; Andrea Kriska, PhD; Daniel Edmundowicz, MD; Mary L. Klem, PhD, MLIS; Janet Bonk, RN, MPH; Jennifer Rush, MPH; Rebecca Danchenko, BS; Barb Elnyczky, MA; Karen Vujevich, RN-BC, MSN, CRNP; Janet Krulia, RN ,BSN ,CDE; Donna Wolf, MS; Juliet Mancino, MS, RD, CDE, LDN; Pat Harper, MS, RD, LDN; Anne Mathews, MS, RD, LDN

Brown University Rena R. Wing, PhD; Vincent Pera, MD; John Jakicic, PhD; Deborah Tate, PhD; Amy Gorin, PhD; Renee Bright, MS; Pamela Coward, MS, RD; Natalie Robinson, MS, RD; Tammy Monk, MS; Kara Gallagher, PhD; Anna Bertorelli, MBA, RD; Maureen Daly, RN; Tatum Charron, BS; Rob Nicholson, PhD; Erin Patterson, BS; Julie Currin, MD; Linda Foss, MPH; Deborah Robles; Barbara Bancroft, RN, MS; Jennifer Gauvin, BS; Deborah Maier, MS; Caitlin Egan, MS; Suzanne Phelan, PhD; Hollie Raynor, PhD, RD; Don Kieffer, PhD; Douglas Raynor, PhD; Lauren Lessard, BS; Kimberley Chula-Maguire, MS; Erica Ferguson, BS, RD; Richard Carey, BS; Jane Tavares, BS; Heather Chenot, MS; JP Massaro, BS

The University of Texas Health Science Center at San Antonio Steve Haffner, MD; Maria Montez, RN, MSHP, CDE; Connie Mobley, PhD, RD; Carlos Lorenzo, MD

University of Washington/VA Puget Sound Health Care System Steven E. Kahn, MB, ChB; Brenda Montgomery, MS, RN, CDE; Robert H. Knopp, MD; Edward W. Lipkin, MD, PhD; Matthew L. Maciejewski, PhD; Dace L. Trence, MD; Roque M. Murillo, BS; S. Terry Barrett, BS

Southwestern American Indian Center, Phoenix, Arizona and Shiprock, New Mexico William C. Knowler, MD, DrPH; Paula Bolin, RN, MC; Tina Killean, BS; Carol Percy, RN; Rita Donaldson, BSN; Bernadette Todacheenie, EdD; Justin Glass, MD; Sarah Michaels, MD; Jonathan Krakoff, MD; Jeffrey Curtis, MD, MPH; Peter H. Bennett, MB, FRCP; Tina Morgan; Ruby Johnson; Cathy Manus; Janelia Smiley; Sandra Sangster; Shandiin Begay, MPH; Minnie Roanhorse; Didas Fallis, RN; Nancy Scurlock, MSN, ANP; Leigh Shovestull, RD

\section{Coordinating Center}

Wake Forest University School of Medicine Mark A. Espeland, PhD; Judy Bahnson, BA; Lynne Wagenknecht, DrPH; David Reboussin, PhD; W. Jack Rejeski, PhD; Wei Lang, PhD; Alain Bertoni, MD, MPH; Mara Vitolins, DrPH; Gary Miller, PhD; Paul Ribisl, PhD; Kathy Dotson, BA; Amelia Hodges, BS; Patricia Hogan, MS; Kathy Lane, BS; Carrie Combs, BS; Christian Speas, BS; Delia S. West, PhD; William Herman, MD, MPH

Central Resources Centers
DXA Reading Center, University of California at San Francisco Michael Nevitt, PhD; Ann Schwartz, PhD; John Shepherd, PhD; Jason Maeda, MPH; Cynthia Hayashi; Michaela Rahorst; Lisa Palermo, MS, MA

Central Laboratory, Northwest Lipid Research Laboratories Santica M. Marcovina, PhD, ScD; Greg Strylewicz, MS

ECG Reading Center, EPICARE, Wake Forest University School of Medicine Ronald J. Prineas, MD, PhD; Zhu-Ming Zhang, MD; Charles Campbell, AAS, BS; Sharon Hall

Diet Assessment Center, University of South Carolina, Arnold School of Public Health, Center for Research in Nutrition and Health Disparities Elizabeth J Mayer-Davis, PhD; Cecilia Farach, DrPH

Federal Sponsors

National Institute of Diabetes and Digestive and Kidney Diseases: Barbara Harrison, MS; Susan Z.Yanovski, MD; Van S. Hubbard, MD PhD

National Heart, Lung, and Blood Institute: Lawton S. Cooper, MD, MPH; Eva Obarzanek, PhD, MPH, RD; Denise Simons-Morton, MD, PhD

Centers for Disease Control and Prevention: David F. Williamson, PhD; Edward W. Gregg, PhD

Funding and Support

This study is supported by the Department of Health and Human Services through the following cooperative agreements from the National Institutes of Health: DK57136, DK57149, DK56990, DK57177, DK57171, DK57151, DK57182, DK57131, DK57002, DK57078, DK57154, DK57178, DK57219, DK57008,

DK57135, and DK56992. The following federal agencies have contributed support: National Institute of Diabetes and Digestive and Kidney Diseases; National Heart, Lung, and Blood Institute; National Institute of Nursing Research; National Center on Minority Health and Health Disparities; Office of Research on Women's Health; and the Centers for Disease Control and Prevention. This research was supported in part by the Intramural Research Program of the National Institute of Diabetes and Digestive and Kidney Diseases. The Indian Health Service (I.H.S.) provided personnel, medical oversight, and use of facilities. The opinions expressed in this paper are those of the authors and do not necessarily reflect the views of the I.H.S. or other funding sources. Additional support was received from The Johns Hopkins Medical Institutions Bayview General Clinical Research Center (M01-RR-02719); the Massachusetts General Hospital Mallinckrodt General Clinical Research Center (M01-RR01066); the University of Colorado Health Sciences Center General Clinical Research Center (M01 RR00051) and Clinical Nutrition Research Unit (P30 DK48520); the University of Tennessee at Memphis General Clinical Research Center (M01RR00211-40); the University of Pittsburgh General Clinical Research Center (M01 RR000056 44) and NIH grant (DK 046204); and the University of Washington/NA Puget Sound Health Care System Medical Research Service, Department of Veterans Affairs.

The following organizations have committed to make major contributions to Look AHEAD: Federal Express; Health Management Resources; Johnson \& Johnson, LifeScan Inc.; Optifast-Novartis Nutrition; Roche Pharmaceuticals; Ross Product Division of Abbott Laboratories; Slim-Fast Foods Company; and Unilever.

\section{Author Details}

1Department of Epidemiology, Columbia Mailman School of Public Health, New York, NY, USA, ${ }^{2}$ Department of Epidemiology, Johns Hopkins Bloomberg School of Public Health, Baltimore, MD, USA, ${ }^{3}$ Division of General Internal Medicine, Johns Hopkins School of Medicine, Baltimore, MD, USA, ${ }^{4}$ Department of Biostatistics, Johns Hopkins Bloomberg School of Public Health, Baltimore, MD, USA, ${ }^{5}$ Division of Internal Medicine, University of Pittsburgh, Pittsburgh, PA, USA, 6 Department of Medicine, St. Luke's—Roosevelt Hospital Center, New York, NY, USA, Division of General Internal Medicine and Health Services Research, Department of Medicine, David Geffen School of Medicine at UCLA, Los Angeles, CA, USA and ${ }^{8}$ Department of Psychiatry, University of Pennsylvania, Philadelphia, PA, USA

Received: 23 December 2008 Accepted: 4 June 2010

Published: 4 June 2010 


\section{References}

1. National Institutes of Health NHLBI: Clinical Guidelines on the Identification, Evaluation, and Treatment of Overweight and Obesity in Adults. 1998:98-4083. Ref Type: Report

2. Flegal KM, Carroll MD, Kuczmarski RJ, Johnson CL: Overweight and obesity in the United States: prevalence and trends, 1960-1994. Int J Obes Relat Metab Disord 1998, 22:39-47.

3. Flegal KM, Carroll MD, Ogden $\mathrm{CL}$, Johnson $\mathrm{CL}$ : Prevalence and trends in obesity among US adults, 1999-2000. JAMA 2002, 288:1723-1727.

4. Fontaine KR, Redden DT, Wang C, Westfall AO, Allison DB: Years of life lost due to obesity. JAMA 2003, 289:187-193.

5. Flegal KM, Carroll MD, Kuczmarski RJ, Johnson CL: Overweight and obesity in the United States: prevalence and trends, 1960-1994. Int J Obes Relat Metab Disord 1998, 22:39-47.

6. Faith MS, Fontaine KR, Baskin ML, Allison DB: Toward the reduction of population obesity: macrolevel environmental approaches to the problems of food, eating, and obesity. Psychol Bull 2007, 133:205-226.

7. Lopez RP: Neighborhood risk factors for obesity 1. Obesity (Silver Spring) 2007, 15:2111-2119.

8. Papas MA, Alberg AJ, Ewing R, Helzlsouer KJ, Gary TL, Klassen AC: The built environment and obesity 1. Epidemiol Rev 2007, 29:129-143.

9. Cohen DA, Mason K, Bedimo A, Scribner R, Basolo V, Farley TA: Neighborhood physical conditions and health. Am J Public Health 2003, 93:467-471.

10. Diez Roux AV: Investigating neighborhood and area effects on health. Am J Public Health 2001, 91:1783-1789.

11. Franzini L, Caughy M, Spears W, Fernandez Esquer ME: Neighborhood economic conditions, social processes, and self-rated health in lowincome neighborhoods in Texas: a multilevel latent variables model 1. Soc Sci Med 2005, 61:1135-1150.

12. Diez-Roux AV, Nieto FJ, Muntaner C, Tyroler HA, Comstock GW, Shahar E, et al.: Neighborhood environments and coronary heart disease: a multilevel analysis. Am J Epidemiol 1997, 146:48-63.

13. Diez-Roux AV, Nieto FJ, Caulfield L, Tyroler HA, Watson RL, Szklo M: Neighbourhood differences in diet: the Atherosclerosis Risk in Communities (ARIC) Study. J Epidemiol Community Health 1999, 53:55-63.

14. Diez Roux AV, Merkin SS, Arnett D, Chambless L, Massing M, Nieto FJ, et al:: Neighborhood of residence and incidence of coronary heart disease. N Engl J Med 2001, 345:99-106.

15. Diez Roux AV, Jacobs DR, Kiefe Cl: Neighborhood characteristics and components of the insulin resistance syndrome in young adults: the coronary artery risk development in young adults (CARDIA) study. Diabetes Care 2002, 25:1976-1982.

16. Diez Roux AV: Residential environments and cardiovascular risk. $J$ Urban Health 2003, 80:569-589.

17. Henderson C, Diez Roux AV, Jacobs DR Jr, Kiefe Cl, West D, Williams DR: Neighbourhood characteristics, individual level socioeconomic factors, and depressive symptoms in young adults: the CARDIA study. J Epidemiol Community Health 2005, 59:322-328.

18. Lisabeth LD, Diez Roux AV, Escobar JD, Smith MA, Morgenstern LB: Neighborhood environment and risk of ischemic stroke: the brain attack surveillance in Corpus Christi (BASIC) Project. Am J Epidemiol 2007, 165:279-287.

19. Nordstrom CK, Diez Roux AV, Jackson SA, Gardin JM: The association of personal and neighborhood socioeconomic indicators with subclinical cardiovascular disease in an elderly cohort. The cardiovascular health study. Soc Sci Med 2004, 59:2139-2147.

20. Schootman M, Andresen EM, Wolinsky FD, Malmstrom TK, Miller JP, Yan Y, et al:: The effect of adverse housing and neighborhood conditions on the development of diabetes mellitus among middle-aged African Americans. Am J Epidemio/ 2007, 166:379-387.

21. Schootman M, Andresen EM, Wolinsky FD, Malmstrom TK, Miller JP, Miller DK: Neighbourhood environment and the incidence of depressive symptoms among middle-aged African Americans. J Epidemiol Community Health 2007, 61:527-532.

22. Wang MC, Kim S, Gonzalez AA, MacLeod KE, Winkleby MA Socioeconomic and food-related physical characteristics of the neighbourhood environment are associated with body mass index. Epidemiol Community Health 2007, 61:491-498.
23. Van Lenthe FJ, Mackenbach JP: Neighbourhood deprivation and overweight: the GLOBE study. Int J Obes Relat Metab Disord 2002 26:234-240.

24. Wang MC, Kim S, Gonzalez AA, MacLeod KE, Winkleby MA: Socioeconomic and food-related physical characteristics of the neighbourhood environment are associated with body mass index. J Epidemiol Community Health 2007, 61:491-498.

25. Tuomilehto J, Lindstrom J, Eriksson JG, Valle TT, Hamalainen H, llanneParikka P, et al.: Prevention of type 2 diabetes mellitus by changes in lifestyle among subjects with impaired glucose tolerance 1. NEngl J Med 2001, 344:1343-1350.

26. Whelton PK, Appel LJ, Espeland MA, Applegate WB, Ettinger WH Jr, Kostis $\mathrm{JB}$, et al:: Sodium reduction and weight loss in the treatment of hypertension in older persons: a randomized controlled trial of nonpharmacologic interventions in the elderly (TONE). TONE Collaborative Research Group 1. JAMA 1998, 279:839-846.

27. Pi-Sunyer $X$, Blackburn G, Brancati FL, Bray GA, Bright R, Clark JM, et al: Reduction in weight and cardiovascular disease risk factors in individuals with type 2 diabetes: one-year results of the look AHEAD trial 1. Diabetes Care 2007, 30:1374-1383.

28. Ryan DH, Espeland MA, Foster GD, Haffner SM, Hubbard VS, Johnson KC, et al.: Look AHEAD (Action for Health in Diabetes): design and methods for a clinical trial of weight loss for the prevention of cardiovascular disease in type 2 diabetes. Control Clin Trials 2003, 24:610-628.

29. Diez Roux AV, Jacobs DR, Kiefe Cl: Neighborhood characteristics and components of the insulin resistance syndrome in young adults: the coronary artery risk development in young adults (CARDIA) study. Diabetes Care 2002, 25:1976-1982.

30. Winkleby MA, Cubbin C: Influence of individual and neighbourhood socioeconomic status on mortality among black, Mexican-American, and white women and men in the United States. J Epidemiol Community Health 2003, 57:444-452.

31. Krieger N, Chen JT, Waterman PD, Soobader MJ, Subramanian SV, Carson $\mathrm{R}$ : Geocoding and monitoring of US socioeconomic inequalities in mortality and cancer incidence: does the choice of area-based measure and geographic level matter?: the Public Health Disparities Geocoding Project. Am J Epidemio/ 2002, 156:471-482.

32. Diez-Roux AV: Multilevel analysis in public health research. Annu Rev Public Health 2000, 21:171-192.

33. Bingenheimer JB, Raudenbush SW: Statistical and substantive inferences in public health: issues in the application of multilevel models. Annu Rev Public Health 2004, 25:53-77.

34. Klassen AC, Curriero FC, Hong JH, Williams C, Kulldorff M, Meissner HI, et al:: The role of area-level influences on prostate cancer grade and stage at diagnosis. Prev Med 2004, 39:441-448.

35. Humpel N, Owen N, Leslie E: Environmental factors associated with adults' participation in physical activity: a review. Am J Prev Med 2002 22:188-199.

36. Addy CL, Wilson DK, Kirtland KA, Ainsworth BE, Sharpe P, Kimsey D: Associations of perceived social and physical environmental supports with physical activity and walking behavior. Am J Public Health 2004, 94:440-443.

37. Suminski RR, Poston WS, Petosa RL, Stevens E, Katzenmoyer LM: Features of the neighborhood environment and walking by U.S. adults. Am J Prev Med 2005, 28:149-155.

38. Moudon AV, Lee C, Cheadle AD, Garvin C, Rd DB, Schmid TL, et al: Attributes of environments supporting walking. Am J Health Promot 2007, 21:448-459.

39. Librett JJ, Yore MM, Schmid TL, Kohl HW III: Are self-reported physical activity levels associated with perceived desirability of activity-friendly communities? Health Place 2007, 13:767-773.

40. Cohen DA, McKenzie TL, Sehgal A, Williamson S, Golinelli D, Lurie N: Contribution of public parks to physical activity. Am J Public Health 2007, 97:509-514

41. Diez Roux AV, Evenson KR, McGinn AP, Brown DG, Moore L, Brines S, et al:: Availability of recreational resources and physical activity in adults. Am J Public Health 2007, 97:493-499.

42. Cheadle A, Psaty BM, Curry S, Wagner E, Diehr P, Koepsell T, et al.: Community-level comparisons between the grocery store environment and individual dietary practices. Prev Med 1991, 20:250-261 
43. Morland K, Wing S, Diez RA: The contextual effect of the local food environment on residents' diets: the atherosclerosis risk in communities study. Am J Public Health 2002, 92:1761-1767.

44. Moore LV, Diez Roux AV: Associations of neighborhood characteristics with the location and type of food stores. Am J Public Health 2006, 96:325-331.

45. Inagami S, Cohen DA, Finch BK, Asch SM: You are where you shop: grocery store locations, weight, and neighborhoods. Am J Prev Med 2006, 31:10-17.

46. Glass TA, Rasmussen MD, Schwartz BS: Neighborhoods and obesity in older adults: the Baltimore Memory Study. Am J Prev Med 2006, 31:455-463.

47. Boehmer TK, Hoehner CM, Deshpande AD, Brennan Ramirez LK, Brownson RC: Perceived and observed neighborhood indicators of obesity among urban adults. Int J Obes (Lond) 2007 in press.

48. Rundle A, Roux AV, Free LM, Miller D, Neckerman KM, Weiss CC: The urban built environment and obesity in New York City: a multilevel analysis. Am J Health Promot 2007, 21:326-334.

49. Wang MC, Kim S, Gonzalez AA, MacLeod KE, Winkleby MA Socioeconomic and food-related physical characteristics of the neighbourhood environment are associated with body mass index. Epidemiol Community Health 2007, 61:491-498.

50. Papas MA, Alberg AJ, Ewing R, Helzlsouer KJ, Gary TL, Klassen AC: The built environment and obesity 1. Epidemiol Rev 2007, 29:129-143.

\section{Pre-publication history}

The pre-publication history for this paper can be accessed here: http://www.biomedcentral.com/1471-2458/10/312/prepub

doi: 10.1186/1471-2458-10-312

Cite this article as: Gary-Webb et al., Neighborhood and weight-related health behaviors in the Look AHEAD (Action for Health in Diabetes) Study BMC Public Health 2010, 10:312

Submit your next manuscript to BioMed Central and take full advantage of:

- Convenient online submission

- Thorough peer review

- No space constraints or color figure charges

- Immediate publication on acceptance

- Inclusion in PubMed, CAS, Scopus and Google Scholar

- Research which is freely available for redistribution

Submit your manuscript at www.biomedcentral.com/submit 